\title{
Comparing RAS with and without biofloc: Transcriptional response of immune-related genes in Litopenaeus vannamei post-larvae
}

\section{Comparación de SAR con y sin biofloc: Respuesta transcripcional de genes relacionados con el sistema inmune en postlarvas de Litopenaeus vannamei}

Comparando o SAR com e sem biofloc: Resposta transcricional de genes relacionados ao sistema imune em pós-larvas de Litopenaeus vannamei

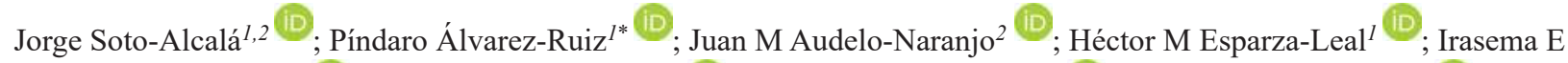
Luis-Villaseñor $^{2}{ }^{(\mathbb{D}}$; José A Estrada-Godínez ${ }^{2}{ }^{\mathbb{D}}$; Antonio Luna-González ${ }^{1}{ }^{\mathbb{D}}$; Carina Gámez-Jiménez $^{l}$ (D); Genaro Diarte-Plata ${ }^{l}$.
}

${ }^{1}$ Instituto Politécnico Nacional. Centro Interdisciplinario de Investigación para el Desarrollo Integral regional, Unidad Sinaloa (CIIDIR-

Sinaloa), Guasave, Sinaloa, México.

${ }^{2}$ Universidad Autónoma de Sinaloa. Facultad de Ciencias del Mar, Mazatlán, Sinaloa, México.

Received: May 23, 2018; accepted: April 12, 2019

To cite this article:

Soto-Alcalá J, Álvarez-Ruiz P, Audelo-Naranjo JM, Esparza-Leal HM, Luis-Villaseñor IE, Estrada-Godínez JA, LunaGonzález A, Gámez-Jiménez C, Diarte-Plata G. Comparing RAS with and without biofloc: Transcriptional response of immune-related genes in Litopenaeus vannamei post-larvae. Rev Colomb Cienc Pecu 2020; 33(1):32-43.

DOI: $\underline{\text { https://doi.org/10.17533/udea.rccp.v33n1a03 }}$

\section{(cc) $\mathrm{BY}-\mathrm{NC}-\mathrm{SA}$}

\footnotetext{
*Corresponding Author. Boulevard Juan de Dios Bátiz Paredes \#250, C.P. 81101, Guasave, Sinaloa, Mexico.

E mail: pindaroalvarez@hotmail.com; palvarez@ipn.mx
} 


\begin{abstract}
Background: Shrimp farming is evolving from semi-intensive to hyper-intensive systems with biofloc technology and water recirculation systems. Objective: To evaluate the transcriptional response promoted by biofloc on shrimp (Litopenaeus vannamei) under a recirculating aquaculture system (RAS). Methods: Quantitative real-time RT-PCR was used to monitor seven key genes related to the immune system in shrimp post-larvae, reared in a RAS with and without biofloc (BF and no$\mathrm{BF}$ ). In addition, we present for the first time nucleotide sequences of ADP-ribosylation factor 4 (LvArf4) from Litopenaeus vannamei. Results: Transcripts for penaeidin3 (Pen3), penaeidin4 (Pen4), crustin, and Toll receptor (LvToll) genes were upregulated between 3 and $24 \mathrm{~h}$ in both systems, and tumor necrosis factor receptor-associated factor 6 (TRAF6) in no-BF as an early response. Regarding differential expression between treatments, 13 occurrences were encountered. Nine that were higher in BF than in no-BF and four higher in no-BF than in BF. In some sample times, expression of Pen3, crustin, LvToll, TRAF6, IMD, and LvArf4 was higher in BF than in no-BF and in others, expression of Pen3, Pen4, and TRAF6 was higher in no-BF than in BF. Conclusions: BF modulates the transcription of genes related to the immune response in shrimp as an early response. However, the RAS with no-BF promotes a similar response.
\end{abstract}

Keywords: antimicrobial peptide; aquaculture; biofloc; gene expression; Penaeidin; RAS; shrimp; shrimp immune system.

\title{
Resumen
}

Antecedentes: Los cultivos de camarón están evolucionando de sistemas semi-intensivos a hiper-intensivos con biofloc y con recirculación. Objetivo: Evaluar la respuesta transcripcional promovida por el biofloc en un sistema acuícola con recirculación (SAR). Métodos: Monitoreamos mediante RT-PCR cuantitativo siete genes relacionados con el sistema inmune en postlarvas de camarón cultivadas en un SAR con y sin biofloc (BF y no-BF). Además, presentamos por primera vez la secuencia de nucleótidos del factor de ribosilación 4 de ADP (LvArf4) de Litopenaeus vannamei. Resultados: Los genes penaeidina3 (Pen3), penaeidina4 (Pen4), Crustina y Toll (LvToll) se sobre-expresaron entre las 3 y 24 h en ambos sistemas, y el factor 6 asociado al factor de necrosis tumoral (TRAF6) en BF como una respuesta temprana. Con respecto a la expresión diferencial entre los tratamientos, se presentaron 13 ocurrencias. Nueve donde el BF fue mayor que sin-BF y cuatro donde el no-BF fue mayor que el BF. La expresión fue más alta en BF que en no-BF en Pen3, Crustin, LvToll, TRAF6, IMD y LvArf4. En contraste, la expresión fue mayor en no-BF en Pen3, Pen4 y TRAF6. Conclusión: el BF modula la transcripción de los genes relacionados con la respuesta inmune en camarón como una respuesta temprana. Sin embargo, el SAR sin-BF promueve una respuesta similar.

Palabras clave: aquicultura; biofloc; camarón; expresión genética; Penaeidina; péptido antimicrobiano; SAR; sistema inmune de camarón.

\section{Resumo}

Antecedentes: A criação de camarões está evoluindo de sistemas semi-intensivos para hiper-intensivos como tecnologia de bioflocos e sistemas de recirculação. Objetivo: Avaliar a resposta transcricional promovida pelo biofloco em um sistema de aquicultura recirculante (SAR). Métodos: Utilizamos RT-PCR quantitativo em tempo real para monitorar sete genes-chave relacionados ao sistema imune em pós-larvas de camarão, criados em SAR com e sem bioflocos (BF e no-BF). Além disso, apresentamos pela primeira vez sequências nucleotídicas do fator de ribosilação do ADP 4 (LvArf4) de Litopenaeus vannamei. Resultados: Os resultados mostraram que o Penaeidina3 (PEN3), Penaeidina4 (Pen4), Crustina e Toll genes (LvToll) foram sobre-expressos entre 3 e $24 \mathrm{~h}$ em ambos os sistemas, e o Factor de Necrose do Receptor 6 associado e protuberância (TRAF6) no $\mathrm{BF}$ como uma resposta precoce. Com relação à expressão diferencial entre tratamentos, 13 ocorrências foram apresentadas. Nove onde o BF foi maior do que os não-BF e quatro onde o não-BF foi maior do que o BF. A expressão foi maior do que em BF não-BF em Pen3, Crustin, LvToll, TRAF6, IMD e LvArf4. Em contraste, a expressão foi mais elevada no não-BF em Pen3, Pen4 e TRAF6. Conclusões: O BF modula a transcrição de resposta imune relacionada no camarão como um genes de resposta precoce. No entanto, o SAR não BF promove uma resposta semelhante

Palavras-chave: aquicultura; biofloco; camarão; expressão genética; Penaeidina; peptídeo antimicrobiano; SAR; sistema imunológico do camarão. 


\section{Introduction}

World farmed shrimp production volume decreased significantly in 2013 as a result of early mortality syndrome in some countries in Asia and Latin America (FAO, 2014). Therefore, efforts have been made to develop hyperintensive crops through biofloc technology (Emerenciano et al., 2013). The biofloc is a complex of living organisms that are closely associated with particulate organic matter and are maintained in suspension by continuous aeration. Plankton and bacteria, which are part of this complex, metabolize nitrogenous waste excreted by fed-farmed animals. This property of biofloc is due to its conformation and is being used worldwide for culturing various aquatic animal species because this system maintains good water quality in densely populated systems (Avnimelech, 2012). In Mexico, some farmers have seen that biofloc has a preventive and even healing capacity against bacterial diseases. It is known that biofloc promotes immunological and antioxidant responses in different shrimp species (Xu and Pan, 2014; Cardona et al., 2015). Shrimp immune system depends mainly on innate immunity and is divided in humoral and cellular immunity (Lee and Söderhäll, 2002; Cerenius and Söderhäll, 2004; Jiravanichpaisal et al., 2006). In crustaceans, innate immunity recognizes invading microorganisms and triggers various defense mechanisms to eliminate pathogens (Söderhäll and Cerenius, 1992). The pathway through which cells identify microorganisms is through pattern recognition receptors (PRRs). This PRRs regulate the expression of downstream immune-related genes after stimulation by pathogens associated molecular patterns (PAMPs), such as lipopolysaccharide (LPS), $\beta$-I,3-glucans, and peptidoglycans (Wang and Wang 2013; Chen et al., 2016).

Hence, our hypothesis is that the microorganisms present in a biofloc system (BF) may trigger the immune response of shrimp. In the present study, post-larvae (PL) shrimp were exposed to a RAS with a mature heterotrophic BF or without BF (no-BF), and the transcriptional response of seven immunerelated genes was monitored.

\section{Materials and methods}

\section{Ethical considerations}

This study complies with the Mexican official Standard NOM-0062-ZOO-1999, technical specifications for production, care and use of laboratory animals.

\section{Experimental culture systems}

Two identical RAS (800 L each) were designed. Each system consisted of the main tank with $400 \mathrm{~L}$ of seawater, pumped to an elevated tank of $100 \mathrm{~L}$. The water was distributed among 6 glass aquariums ( $50 \mathrm{~L}$ each) by gravity $(\sim 50 \mathrm{~L} / \mathrm{h})$. The aquariums were connected to a return tube to the main tank. Every container was supplied with vigorous aeration using air stones in aquariums and aero-tube in the main tank. Bunches of polypropylene fibers $(50 \mathrm{~g} / \mathrm{L})$ (Brand COVERPACK-Mexico) were placed into the main tank of RAS no-BF, as a substrate for a biological filter.

Juvenile shrimp $(1 \pm 0.5 \mathrm{~g}=30$ per aquarium $)$ were placed in the system, and cane molasses was added as a source of organic carbon $(0.2 \mathrm{~g} / \mathrm{L}$ daily) to promote biofloc formation. When the $\mathrm{BF}$ reached the appropriate parameters (Table 2), the juvenile shrimp were removed from the aquariums for the transcriptional response experiment.

\section{Experimental design}

One batch of 2,000 PL (mean body weight of $150 \pm 30 \mathrm{mg}$ ) was acquired from a commercial hatchery and acclimatized for $24 \mathrm{~h}$ at $35 \mathrm{~g} \mathrm{~L}^{-1}$ salinity before being placed in the experimental systems. 
After removing juvenile shrimp from experimental aquariums (above), 150 PL shrimp were stocked into each aquarium. At this time, we collected six PL shrimp to evaluate the original expression (T0). Later, one PL shrimp per replicate (six per treatment) was collected at different times $(3,6,9,12,18,24,36,48$, and 72 h). Each PL shrimp was placed individually in Trizol reagent for RNA extraction and stored at $-70{ }^{\circ} \mathrm{C}$ until analyses.

\section{Physicochemical parameters}

Prior to the experiment, $\mathrm{pH}$, water salinity, temperature $\left({ }^{\circ} \mathrm{C}\right)$, and dissolved oxygen (DO; $\mathrm{mg} \mathrm{L}^{-1}$ ) were measured daily in each aquarium of both systems. Total ammonia $\left(\mathrm{mg} \mathrm{L}^{-1}\right)$, nitrite $\left(\mathrm{mg} \mathrm{L}^{-1}\right)$, nitrate $\left(\mathrm{mg} \mathrm{L}^{-1}\right)$, phosphate $\left(\mathrm{mg} \mathrm{L}^{-1}\right)$, alkalinity (mg $\left.\mathrm{CaCO}_{3} \mathrm{~L}^{-1}\right)$, and total suspended solids (TSS, $\mathrm{mg} \mathrm{L}^{-1}$ ) were analyzed twice a week until suitable levels for a biofloc system were reached. The chemical parameters were analyzed following the methods described by Strikland and Parsons (1972) and APHA (1998).

\section{Bacterial analyses}

Water samples for bacterial analyses were collected from each aquarium following standard procedures (APHA, 1998; Gómez-Gil, 2006). Presumptive Vibrio sp. was detected in a plate per triplicate with Thiosulfate-citratebile salts-sucrose agar (TCBS agar; Difco, Detroit, MI, USA) supplemented with $2.5 \%$ $\mathrm{NaCl}$ and incubated for $24 \mathrm{~h}$ at $30{ }^{\circ} \mathrm{C}$ before counting (CFU mL $\mathrm{mL}^{-1}$ ). Presumptive Bacillus sp. were determined. Briefly, water samples were incubated at $80^{\circ} \mathrm{C}$ for $10 \mathrm{~min}$ to debug the sample of non-spore forming bacteria. Subsequently, Bacillus sp were detected in a plate per triplicate with trypticase soy agar (TSA, BD, Bioxon, Sparks, MD, USA) supplemented with $2 \% \mathrm{NaCl}$ and incubated for $24 \mathrm{~h}$ at $37^{\circ} \mathrm{C}$ before counting.

\section{RNA extraction and $c D N A$ synthesis}

Total RNA was extracted from individual PL using $1 \mathrm{~mL}$ of TRI REAGENT (Molecular Research Center, Inc. Cincinnati, OH, USA) following manufacturer's instructions and washing RNA pellet twice before drying. Total RNA was quantified on a NanoPhotometer (Pearl, Implen ${ }^{\circledR}$, Westlake Village, CA, USA) considering the absorbance ratio $260 / 280 \mathrm{~nm}$ between 1.8 and 2.0 as acceptable purity range.

To transcribe the cDNA, an aliquot of the total RNA was diluted at $300 \mathrm{ng} / \mu \mathrm{L}(25 \mu \mathrm{L})$ and then treated with DNAse I (1 U/ $\mu \mathrm{L}$, Sigma-Aldrich, St. Louis, MO, USA) following manufacturer's instructions.

The cDNA synthesis was performed with Improm II (Promega, Madison, WI, USA) and the oligo $\left(\mathrm{dT}_{20}\right)$ primer using $1.0 \mu \mathrm{g}$ of RNA, following manufacturer's instructions. The cDNA was diluted 10 times with ultrapure water and stored at $-70{ }^{\circ} \mathrm{C}$ until qPCR analysis and $2.5 \mu \mathrm{L}$ of this cDNA dilution was used as template in each qRT-PCR reaction.

Primer design and detection of ADP ribosylation factor 4 in Litopenaeus vannamei

Arf4 primers were designed from Marsupenaeus japonicus (GeneBank accession GQ279375) and Penaeus monodon (GeneBank accession KM210090) to amplify the full sequence of LvArf4 (543 bp). The PCR products were resolved on a $1.5 \%$ agarose gel. The bands were excised from the gel and purified with GENECLEAN Kit (MP Biomedicals, Santa Ana, CA, USA), cloned in the pGEM-T Easy Vector System (Promega), and sequenced by GENEWIZ (South Plainfield, NJ, USA).

Specific primers for RT-qPCR were designed from the confirmed sequences (Table 1). 


\section{Quantitative real-time $P C R \quad(R T-q P C R)$ analysis}

Relative expression was measured by RTqPCR with specific primers (Table 1) using a CFX96 Real-Time PCR thermal cycler (BioRad Laboratories, Hercules, CA, USA). The expression of target genes was normalized with the geometric mean of $40 \mathrm{~S}-\mathrm{S} 24, \mathrm{Ef}-2$, and $\beta$-actin (Table 1). The stability of reference genes, $\mathrm{Cq}$ transformation, PCR master mix, efficiency, and amplification conditions were done as described by Alvarez-Ruiz et al. (2015).

\section{Statistical analyses}

Up-regulated expression was determined by statistical analysis using a two-way ANOVA. Expressions higher than the control group (T0) were considered as up-regulated. Statistical differences in the bacterial population between treatments were done by Student's $t$-test. The analyses were conducted using STATISTICA package v6 (StatSoft, Tulsa, OK, USA). Statistical significance was set at $(\mathrm{p}<0.05)$.

Table 1. Primers used for RT-qPCR in this study.

\begin{tabular}{|c|c|c|c|c|c|}
\hline Immune system & Gene & Primer & Sequence $5^{\prime}-3^{\prime}$ & $\begin{array}{l}\text { Product } \\
\text { size } \\
\text { (bp) }\end{array}$ & Reference \\
\hline \multirow{3}{*}{ Antimicrobial peptide } & Penaeidin 3 & $\begin{array}{l}\text { qLvPEN3-F } \\
\text { qLvPEN3-R }\end{array}$ & $\begin{array}{l}\text { CACCCTTCGTGAGACCTTTG } \\
\text { AATATCCCTTTCCCACGTGAC }\end{array}$ & 141 & $\begin{array}{c}\text { Han-Chin Wang et } \\
\text { al. } 2010\end{array}$ \\
\hline & Penaeidin 4 & $\begin{array}{l}\text { qLvPEN4-F } \\
\text { qLvPEN4-R }\end{array}$ & $\begin{array}{l}\text { GCCCGTTACCCAAACCATC } \\
\text { CCGTATCTGAAGCAGCAAAGTC }\end{array}$ & 106 & $\begin{array}{c}\text { Han-Chin Wang et } \\
\text { al. } 2010\end{array}$ \\
\hline & Crustin & $\begin{array}{l}\text { qLvCrustin-F } \\
\text { qLvCrustin-R }\end{array}$ & $\begin{array}{l}\text { GAGGGTCAAGCCTACTGCTG } \\
\text { ACTTATCGAGGCCAGCACAC }\end{array}$ & 157 & $\begin{array}{c}\text { Han-Chin Wang et } \\
\text { al. } 2010\end{array}$ \\
\hline \multirow{4}{*}{$\begin{array}{l}\text { Pattern recognition } \\
\text { receptor } \\
\text { and signal transduction }\end{array}$} & $\begin{array}{l}\text { Litopenaeus vannamei } \\
\text { Toll }\end{array}$ & $\begin{array}{l}\text { qLvToll-F } \\
\text { qLvToll-R }\end{array}$ & $\begin{array}{l}\text { ATGTGCGTGCGGATACATTA } \\
\text { GGGTGTTGGATGTCGAGAGT }\end{array}$ & 241 & $\begin{array}{c}\text { Han-Chin Wang et } \\
\text { al. } 2010\end{array}$ \\
\hline & $\begin{array}{l}\text { Tumor necrosis factor } \\
\text { associated factor } 6\end{array}$ & $\begin{array}{l}\text { qLvTRAF6-F } \\
\text { qLvTRAF6-R }\end{array}$ & $\begin{array}{l}\text { AATCATGGCTTGGGCTGTAG } \\
\text { CTTTACCCGCAGGACACATT }\end{array}$ & 165 & This study \\
\hline & $\begin{array}{l}\text { Immune deficiency } \\
\text { homolog }\end{array}$ & $\begin{array}{l}\text { qLvIMD-F } \\
\text { qLvIMD-R }\end{array}$ & $\begin{array}{l}\text { TCAACAAGGGAACCCATCTC } \\
\text { CATATCCTGGGGTTTGTGCT }\end{array}$ & 133 & This study \\
\hline & ADP Ribosylation factor & $\begin{array}{l}\text { qLvADPrf-F } \\
\text { qLvADPrf-R }\end{array}$ & $\begin{array}{l}\text { CGTGAAGATGAACTGCGAGA } \\
\text { AAACCCTGTCCTTGAACTGC }\end{array}$ & 164 & This study \\
\hline \multirow{3}{*}{ Reference genes } & $\begin{array}{l}\text { Ribosomal protein 40S- } \\
\text { S24 }\end{array}$ & $\begin{array}{l}\text { qLv40S-S24-F } \\
\text { qLv40S-S24-R }\end{array}$ & $\begin{array}{l}\text { CAGGCCGATCAACTGTCC } \\
\text { CAATGAGAGCTTGCCTTTCC }\end{array}$ & 204 & $\begin{array}{c}\text { Alvarez Ruiz et al. } \\
2015\end{array}$ \\
\hline & Elongation factor 2 & $\begin{array}{l}\text { qLvEf-F } \\
\text { qLvEf-R }\end{array}$ & $\begin{array}{l}\text { CTGTGGTCTGGTTGGTGTTG } \\
\text { TCAGATGGGTTCTTGGGTTC }\end{array}$ & 141 & $\begin{array}{c}\text { Alvarez Ruiz et al. } \\
2015\end{array}$ \\
\hline & $\beta$-actin & $\begin{array}{l}\text { qLvActin-F } \\
\text { qLvActin-R }\end{array}$ & $\begin{array}{l}\text { CCACGAGACCACCTACAAC } \\
\text { AGCGAGGGCAGTGATTTC }\end{array}$ & 142 & Ji et al. 2009 \\
\hline
\end{tabular}




\section{Results}

Water quality and bacterial population

The water quality parameters were within acceptable ranges for shrimp growth at the beginning of the experiment (Table 2). Total Vibrio sp. count presented significantly higher values in no-BF than in $\mathrm{BF}\left(21.9 \times 10^{3} \mathrm{CFU}\right.$ vs. $\left.6.9 \times 10^{3} \mathrm{CFU}\right)$.
There were no sucrose-negative colonies in $\mathrm{BF}$, hence, presenting significant differences in regard to no-BF $\left(18.1 \times 10^{3} \mathrm{CFU}\right)$. There were no differences in sucrose-positive colonies between $\mathrm{BF}$ and no-BF $\left(6.0 \times 10^{3} \mathrm{CFU}\right.$ vs. $4.2 \mathrm{x}$ $10^{3} \mathrm{CFU}$ ) or in populations of Bacillus between $\mathrm{BF}$ and no-BF $\left(6.8 \times 10^{3} \mathrm{CFU}\right.$ vs. $11.3 \times 10^{3}$ CFU) (Table 3).

Table 2. Water quality parameters in biofloc and no-biofloc systems at the beginning of bioassay.

\begin{tabular}{|c|c|c|c|c|c|c|c|c|c|}
\hline Treatment & $\begin{array}{c}\text { TA-N } \\
\left(\mathrm{mg} \mathrm{L}^{-1}\right)\end{array}$ & $\begin{array}{l}\text { NO2-N } \\
\left(\mathrm{mg} \mathrm{L}^{-1}\right)\end{array}$ & $\begin{array}{l}\text { NO3-N } \\
\left(\mathrm{mg} \mathrm{L}^{-1}\right)\end{array}$ & $\begin{array}{c}\text { PO4-P } \\
\left(\mathrm{mg} \mathrm{L}^{-1}\right)\end{array}$ & $\begin{array}{c}\text { SST } \\
\left(\mathrm{mg} \mathrm{L}^{-1}\right)\end{array}$ & $\begin{array}{c}\text { DO } \\
\left(\mathrm{mg} \mathrm{L}^{-1}\right)\end{array}$ & $\begin{array}{c}\text { Temperature } \\
\left({ }^{\circ} \mathrm{C}\right)\end{array}$ & $\begin{array}{c}\text { Salinity } \\
\left(\mathrm{g} \mathrm{L}^{-1}\right)\end{array}$ & pH \\
\hline Biofloc & $0.054 \pm 0.013$ & $0.021 \pm 0.001$ & $0.004 \pm 0.001$ & $0.016 \pm 0.008$ & $226.14 \pm 14.4$ & $8.0 \pm 0.1$ & $26.9 \pm 0.1$ & 35 & 8.3 \\
\hline No-Biofloc & $0.104 \pm 0.013$ & $0.550 \pm 0.005$ & $0.103 \pm 0.013$ & $0.047 \pm 0.003$ & $114.93 \pm 11.4$ & $7.6 \pm 0.1$ & $27.2 \pm 0.0$ & 35 & 8.2 \\
\hline
\end{tabular}

Table 3. Bacterial population in biofloc and no-biofloc systems at the beginning of bioassay.

\begin{tabular}{|c|c|c|c|c|}
\hline Treatment & $\begin{array}{c}\text { Total } \\
\text { Vibrio sp. }\end{array}$ & $\begin{array}{c}\text { Vibrio sp. } \\
\text { sucrose negatives } \\
\left(\mathrm{CFU} / \mathrm{mL} \times 1^{3}\right)\end{array}$ & $\begin{array}{c}\text { Vibrio sp. } \\
\text { sucrose positives } \\
\left(\mathrm{CFU} / \mathrm{mL} \times 10^{3}\right)\end{array}$ & $\begin{array}{c}\text { Total } \\
\text { Bacillus sp. } \\
\left(\text { CFU/mL X 10 } \text { 10 }^{3}\right)\end{array}$ \\
\hline No-Biofloc & $21.92 \pm 3.1^{\mathrm{a}}$ & $18.08 \pm 5.6^{\mathrm{a}}$ & $4.17 \pm 2.0$ & $6.75 \pm 2.8$ \\
\hline Biofloc & $6.93 \pm 3.6^{b}$ & $0.02 \pm 0.0^{b}$ & $6.02 \pm 2.0$ & $11.25 \pm 2.0$ \\
\hline
\end{tabular}

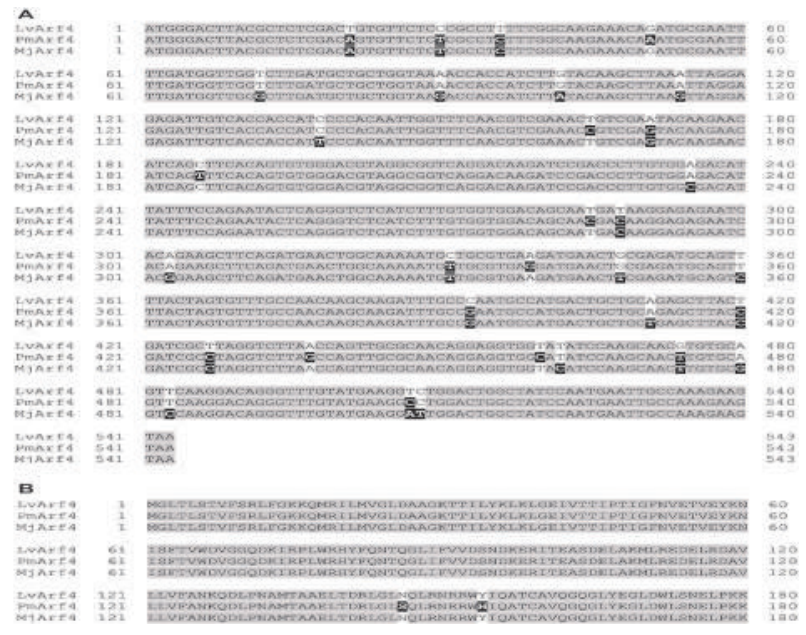

Figure 1. Nucleotide (A) and deduced amino acid (B) sequences alignment of the ADP-ribosylation factor 4 of L. vannamei (LvArf4) from Mexico compared to the corresponding Arf4 sequences from $M$. japonicus and P. monodon. Grey shade indicates identical nucleotides or amino acids in all species (conserved region). Dark shade indicates differences as compared to L. vannamei sequence.
Cloning and sequence analyses of $A D P$ ribosylation factor 4

The full sequence of the ADP ribosylation factor 4 in L. vannamei was sequenced (GenBank ACCESSION MK471369). Blast analyses showed 95 and $97 \%$ nucleotide identity with the Arf4 from M. japonicus and P. monodon, respectively (Figure 1A).

The predicted amino acid sequence of LvArf4 of L. vannamei showed 100 and $99 \%$ identity to MjArf4 and PmArf4, respectively (Figure 1B).

Transcriptional response of shrimp immunerelated genes

Results are grouped below according to the gene role in the shrimp defense mechanism. 
Antimicrobial peptides (Pen3, Pen4, crustin). Pen3 gene was up-regulated at 6 and $24 \mathrm{~h}$ in BF, and 3 and $18 \mathrm{~h}$ in no-BF. The expression level of Pen 3 in no-BF was higher than in $\mathrm{BF}$ at $3 \mathrm{~h}$, but lower at $6 \mathrm{~h}$ (Figure 2A).

Pen4 gene was up-regulated at $3 \mathrm{~h}$ in no-BF and $6 \mathrm{~h}$ in BF. Besides, the expression of Pen4 in no-BF was significantly higher than in the BF at 3 and $48 \mathrm{~h}$ (Figure 2B).

Crustin gene was up-regulated in both systems at 3 and $6 \mathrm{~h}$. The expression of crustin in the BF was significantly higher than in no-BF at $36 \mathrm{~h}$ (Figure 2C).
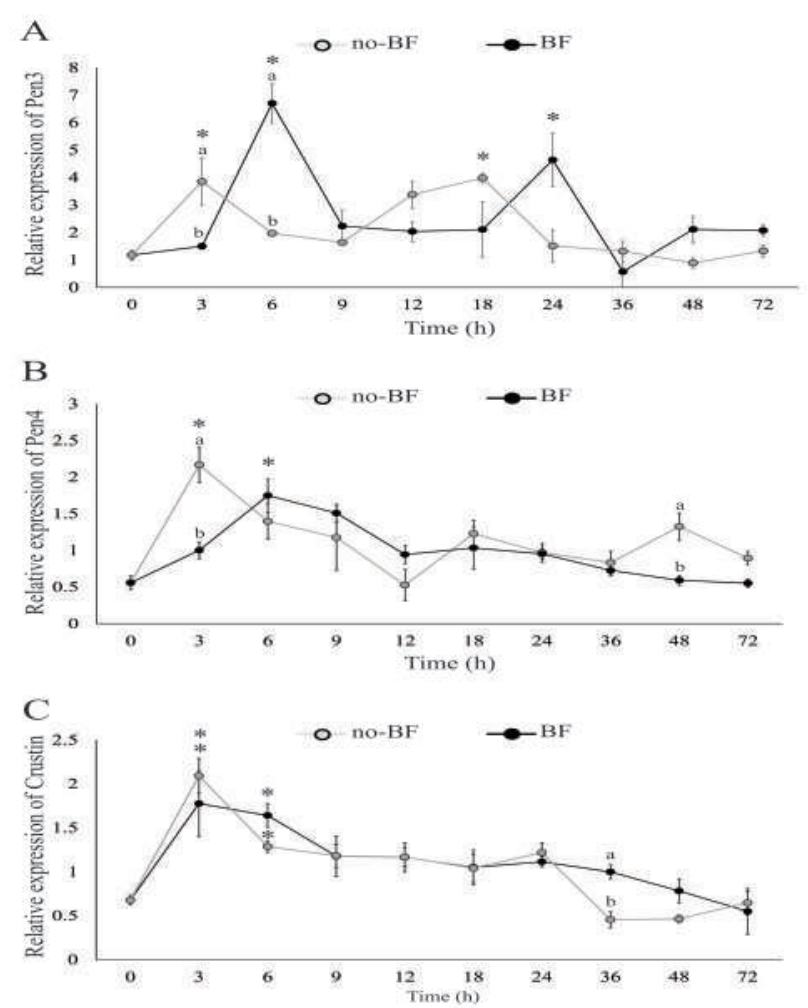

Figure 2. Relative expression of genes related to antimicrobial peptides [Pen3 (A), Pen4 (B) and crustin (C)] in post-larvae after being placed into RAS with biofloc (BF) or without biofloc (no-BF). Up-regulated expression is marked with an asterisk $(*)$. Significant differences between treatments are represented by different letters $(p<0.05)$.

Pattern Recognition receptor and signal transduction (LvToll TRAF6, IMD, Arf4). Upon placing shrimp in the cultures, LvToll was upregulated at $3 \mathrm{~h}$ in no-BF, and at 12, 36, and 48 $\mathrm{h}$ in BF. The expression of LvToll was higher in
$\mathrm{BF}$ than in no-BF at 36 and $48 \mathrm{~h}$ (Figure $3 \mathrm{~A}$ ).

LvTRAF6 expression remained stable in BF. However, LvTRAF6 was up-regulated at $3 \mathrm{~h}$ in no-BF, and was higher than in BF. Contrarily, the expression of TRAF6 was higher in BF at 72 h (Figure 3B).

IMD expression was stable throughout the experiment in both $\mathrm{BF}$ and no-BF. However, IMD expression was higher in $\mathrm{BF}$ than in no-BF at $3 \mathrm{~h}$ (Figure 3C).

Arf4 expression was not up-regulated throughout the experiment. However, the transcription of Arf4 in BF was significantly higher than in no-BF from 36 to $72 \mathrm{~h}$ (Figure 3D).
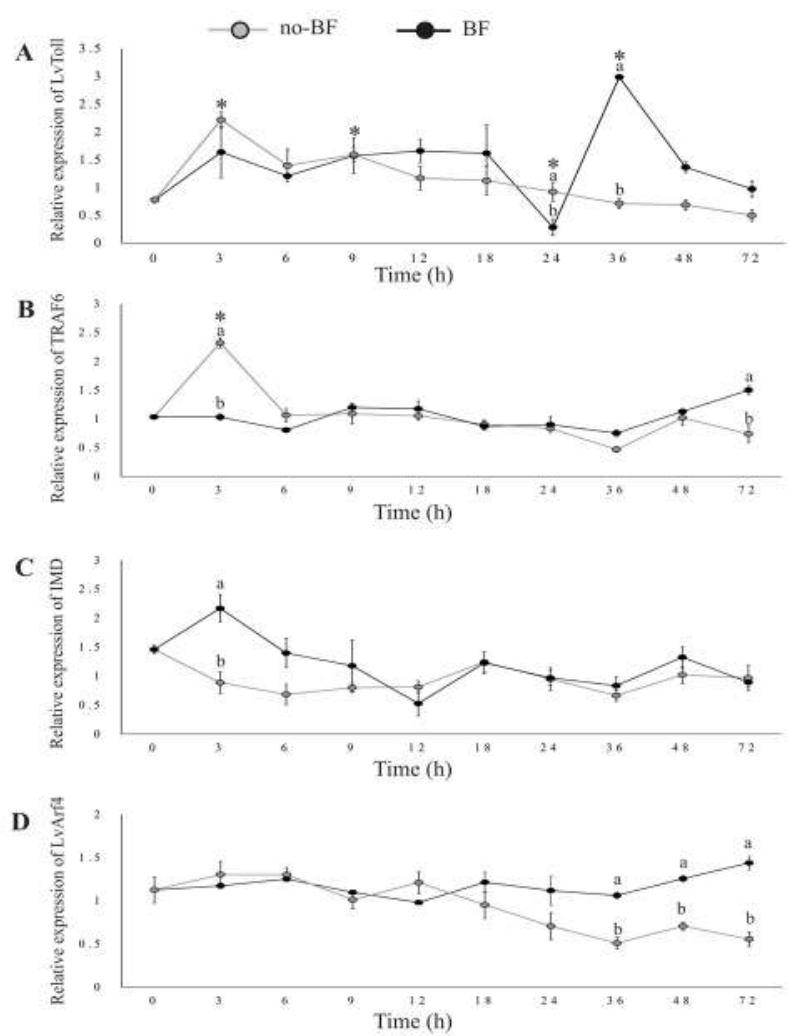

Figure 3. Relative expression of genes related to pattern recognition receptor and signal transduction $[L$. vannamei Toll $(\mathrm{A})$, tumor necrosis factor receptor-associated factor 6 (B), immune deficiency homolog (C), and L. vannamei ADP-ribosylation factor 4 (D)]. Experimental conditions and data presentation are the same as for Figure 2. 


\section{Discussion}

Our understanding of the innate immune response of shrimp, when cultured under biofloc conditions, is still in its early stages. Besides, the RAS-no-BF for rearing shrimp has shown similar productive capacity to the biofloc systems (Esparza-Leal et al., 2015; Ray and Lotz, 2017). Hence, in this study, we evaluated whether the heterotrophic micro-ecosystem (biofloc system) and RAS-no-BF promote the transcription of immune genes in L. vannamei.

We studied the mRNA levels of seven genes through real-time PCR, including ADP-ribosylation factor 4 from L. vannamei, which, to the best of our knowledge, is reported for the first time in this study.

\section{Water quality}

At the beginning of the bioassay, the physicochemical parameters were kept within acceptable ranges for rearing $L$. vannamei in $\mathrm{BF}$ and no-BF cultures (Esparza-Leal et al., 2015; Ray and Lotz, 2017; Schveitzer et al., 2018).

Detection of ADP-ribosylation factor 4 in $L$. vannamei (LvArf4)

An Arf gene has been described for the first time in shrimp (M. japonicus), and showed a delayed transcriptional response against WSSV infection $(24,48,72$, and $96 \mathrm{~h}$ postinfection) (Zhang et al., 2010). Although we lacked information about the Arf4 sequence in L. vannamei, we were able to detect, clone, and sequence for the first time the Arf of $L$. vannamei. Sequence identity was $95 \%$ with MjArf4 sequence (Zhang et al., 2010) and 97\% with PmArf4. This result indicates that Arf4 is a conserved protein among shrimp species.

\section{Expression of antimicrobial peptides}

AMPs constitute vital components of the innate immune system of shrimp, acting as immune effectors by killing or inhibiting the growth of their microbial targets (Destoumieux et al., 1997). Penaeidins are members of a family of antimicrobial peptides that have been proven to be a rapid response mechanism to resist microbial invasions (Destoumieux et al., 2000). Crustin is an antibacterial peptide that has antimicrobial activity against Gram-positive marine bacteria (Jiang et al., 2015). However, recently, an up-regulation of crustin transcripts has been reported after challenging with $V$. parahaemolyticus and WSSV (Rubio-Castro et al., 2016).

We registered an up-regulation of Pen3, Pen4, and crustin transcripts in shrimp during the first hours after contact with BF or no$\mathrm{BF}$, suggesting that the shock between the shrimp internal bacterial population and the microorganisms present in the culture systems promotes the synthesis of AMPs. Since AMPs are stored in shrimp granulocytes, and released after microbial challenge (Destoumieux et al., 2000), the up-regulation recorded in the BF could be an indicator of immune-competence promoted by the microorganisms living in the flocs. On the other hand, the microbial population present in the biological filter could explain the overexpression recorded in no-BF.

Differences in the effectiveness of inhibition have been observed between Pen3 and Pen4 for several species of Bacillus and Micrococcus (Cuthbertson et al., 2008). In the present study, we found a population of Bacillus sp. in both systems, BF and no-BF, and registered an upregulation of the three AMPs between 3 and $6 \mathrm{~h}$. Besides, Pen 3 showed up-regulation at different times in both treatments. This suggests that Pen3 is more sensitive to the microbial population in the culture systems.

Expression of pattern recognition receptor and signal transduction

There are several ways in which shrimp cells respond against pathogens or foreign molecules; this includes Toll-like receptors. The expression 
of the Toll gene in shrimp is stimulated by PAMPs and, thus, induces a response against them (Liu et al., 2016).

Our results showed a sudden up-regulation at $3 \mathrm{~h}$ in no-BF, perhaps as a response to the microorganisms in the water. On the other hand, a remarkable up-regulation was registered at 12,36 , and $48 \mathrm{~h}$ in the BF; this expression was higher than in no-BF at 36 and $48 \mathrm{~h}$, suggesting that after a period of adaptation the LvToll expression is modulated by the culture conditions in the biofloc.

The TRAF6 is one of the key adaptor molecules in the Toll-like receptor signal transduction that triggers downstream cascades involved in innate immunity (Kobayashi et al., 2004). It has been documented that transcription of Toll and TRAF6 genes responds positively to a WSSV infection in a primary hemocyte culture of $P$. monodon (Deepika et al., 2014). In contrast, TRAF6 on shrimp is down-regulated in the intestine after WSSV or Vibrio alginolyticus infection (Wang et al., 2011). In the present study, we recorded a sudden up-regulation of TRAF6 at $3 \mathrm{~h}$ in no-BF, but not in BF. These findings suggest that Toll and TRAF6 play a role in the immune response of shrimp, which may be regulated by pathogens of different etiology or by the microbial community residing in the culture system.

In addition, LvIMD transcription responds to a WSSV infection and can induce expression of Pen4 (Wang et al., 2009). Besides, it is involved in regulating some AMP genes like crustin 1 and 3, anti-lipopolysaccharide factor 6 and 8, and lysozyme 2 (Lan et al., 2013). In this study, transcription of LvIMD remained stable throughout the experiment in both BF and no-BF treatments and, at the same time, we recorded an up-regulation of Pen3, Pen4, and crustin. This indicates that regulation of AMPs in the treatments was not promoted by IMD. Instead, the recorded expression of LvToll and TRAF6 genes suggests that the transcription of AMPs was probably promoted by genes related to the Toll-like receptors pathway. In this sense, Lan et al. (2013) evaluated Feneropenaeus chinensis IMD transcription after a challenge against Vibrio anguillarum and did not find marked differences in hemocytes and no differences in the gill. In contrast, Liu et al. (2016) showed a pronounced transcriptional response of LvIMD in organisms challenged against Gram-negative or Gram-positive bacteria.

Taken together, these findings evidence that further investigations focused on demonstrating how the IMD pathway is related to the innate immune system of the shrimp are necessary.

ADP ribosylation factors (Arfs) are a family of small guanine nucleotide binding proteins that control membrane traffic and organelle structure and have essential functions, including the recruitment of coat proteins that promote sorting of cargo molecules into vesicles (Donaldson and Jackson, 2011). The transcription of LvArf4 showed minor differential expression between no-BF and $\mathrm{BF}$ at 36,48 , and $72 \mathrm{~h}$. These results suggest that the BF promotes a differential regulation of the LvArf4 gene at medium term; a more detailed analysis of this gene is necessary.

In conclusion, the transcriptional response of immune-related genes induced by a RAS with $\mathrm{BF}$ and no-BF occurs as an early response, possibly as a result of the shock with the bacterial community attached to flocs or the biological filter of no-BF. It seems that the biological filter in the RAS no-BF can maintain a bacterial population that promotes a similar response to that elicited in the BF. Whether this differential transcriptional response confers immunity to shrimps against pathogens is something that remains to be further investigated.

\section{Declarations}

\section{Acknowledgments}

We thank to CONACyT for the scholarship (166929) granted to Jorge Soto Alcalá. 


\section{Funding}

This study was funded by Instituto Politécnico Nacional (Project SIP20151682).

\section{Conflicts of interest}

The authors declare they have no conflicts of interest with regard to the work presented in this report.

\section{Author contributions}

Jorge Soto Alcalá performed the shrimp cultures, the quantitative RT-PCR analysis, and wrote the first draft. Píndaro Álvarez Ruiz supervised, corrected and approved the research and the final version of the manuscript. Juan M. Audelo Naranjo contributed to reviewing the literature and interpreting and discussing the methodology for biofloc formation. Héctor M. Esparza Leal contributed to the design and maintenance of biofloc system. Irasema E. Luis Villaseñor contributed to reviewing the literature and interpreting the genetic expression. Jose A. Estrada Godinez contributed to design and maintenance of recirculating aquaculture systems. Antonio Luna Gonzales contributed to reviewing the final version of the manuscript. Carina Gámez Jiménez contributed in maintenance of the experiment and sampling processing. Genaro Diarte Plata conducted the statistical analysis.

\section{References}

Álvarez-Ruiz P, Luna-González A, EscamillaMontes R, Mejía-Ruiz CH, Magallón-Barajas FJ, Llera-Herrera R, Galván-Álvarez DA. Long-lasting Effect Against White Spot Syndrome Virus in Shrimp Broodstock, Litopenaeus vannamei, by LvRab7 Silencing. J World Aquacult Soc 2015; 46(6):571-582. https://doi.org/10.1111/jwas.12236

APHA (American Public Health Association) (USA). Standard Methods for the Examination of Water and Wastewater (20th edn). American
Water Works Association, Washington DC; 1998.

Avnimelech Y. Biofloc technology a practical guidebook. 2nd ed. The World Aquaculture Society, Baton Rouge, United States; 2012.

Cardona E, Saulnier D, Lorgeoux B, Chim L, Gueguen, Y. Rearing effect of biofloc on antioxidant and antimicrobial transcriptional response in Litopenaeus stylirostris shrimp facing an experimental sub-lethal hydrogen peroxide stress. Fish Shellfish Immunol 2015; 45(2):933-939. https://doi.org/10.1016/j.fsi.2015.05.041

Cerenius L, Söderhäll K. The prophenoloxidaseactivating system in invertebrates. Immunol Rev 2004; 198:116-26. https://doi.org/10.1111/ j.0105-2896.2004.00116.x

Chen YY, Chen JC, Kuo YH, Lin YC, Chang YH, Gong HY, Huang CL. Lipopolysaccharide and b-1,3-glucan-binding protein (LGBP) bind to seaweed polysaccharides and activate the prophenoloxidase system in white shrimp Litopenaeus vannamei. Dev Comp Immunol 2016; 55:144-151. https://doi.org/10.1016/j.dci.2015.10.023

Cuthbertson BJ, Deterding LJ, Williams $\mathrm{JG}$, Tomer KB, Etienne K, Blackshear PJ, Büllesbach EE, Grosse PS. Diversity in penaeidin antimicrobial peptide form and function. Dev Comp Immunol 2008; 32:167-181. https://doi.org/10.1016/j.dci.2007.06.009

Deepika A, Sreedharan K, Anutosh Paria, Makesh M, Rajendran KV. Toll-pathway in tiger shrimp (Penaeus monodon) responds to white spot syndrome virus infection: Evidence through molecular characterization and expression profiles of MyD88, TRAF6, and TLR genes. Fish Shellfish Immunol 2014; 41:441-454. https://doi.org/10.1016/j.fsi.2014.09.026

Destoumieux D, BuletP, Loew D, Van Dorsselaer A, Rodriguez J, Bachére E. Penaeidins, a new family of antimicrobial peptides isolated from the shrimp Penaeus vannamei (Decapoda). 
J Biol Chem 1997; 272:28398-28406. doi:10.1074/jbc. 272.45 .28398

Destoumieux D, Muñoz M, Cosseau C, Rodriguez J, Bulet P, Comps M, Bachére E. Penaeidins, antimicrobial peptides with chitinbinding activity, are produced and stored in shrimp granulocytes and released after microbial challenge. J Cell Sci 2000; 113:461469. 10639333

Donaldson JG, Jackson CL. Arf Family $G$ Proteins and their regulators: roles in membrane transport, development and disease. Nat Rev Mol Cell Biol 2011; 12(6):362-375. $\underline{10.1038 / \mathrm{nrm} 3117}$

Emerenciano M, Gaxiola G, Cuzon G. Biofloc Technology (BFT): A Review for Aquaculture Application and Animal Food Industry. In: IntechOpen Edited by Miodrag Darko Matovic: Biomass Now-Cultivation and Utilization. Published: April 30th 2013 $\underline{10.5772 / 53902}$

Esparza-Leal HM, Pereira-Cardozo A, Wasielesky W Jr. Performance of Litopenaeus vannamei postlarvae reared in indoor nursery tanks at high stocking density in clear-water versus biofloc system. Aquac Eng 2015;68:28-34. https://doi.org/10.1016/j.aquaeng.2015.07.004

FAO 2014. The State of World Fisheries and Aquaculture. http://www.fao.org/3/a-i3720e.pdf.

Gómez-Gil B. Manual de bacteriología. CIADMazatlán, Sinaloa, Mexico; 2006.

Han-Chin Wang K, Tseng CW, Lin HY, Chen IT, Chen YH, Chen YM, Chen TY, Yang HL. RNAi knock-down of the Litopenaeus vannamei Toll gene (LvToll) significantly increases mortality and reduces bacterial clearance after challenge with Vibrio harveyi. Dev Comp Immunol 2010; 34:49-58. https://doi.org/10.1016/j.dci.2009.08.003

Jiang HS, Jia WM, Zhao XF, Wang JX. Four crustins involved in antibacterial responses in Marsupenaeus japonicus. Fish Shellfish Immunol 2015; 43:387-395. https://doi.org/10.1016/j.fsi.2015.01.001

Jiravanichpaisal P, Lee BL, Söderhäll K. Cell-mediated immunity in arthropods: hematopoiesis, coagulation, melanization, and opsonization. Immunobiology 2006; 211:21336. https://doi.org/10.1016/j.imbio.2005.10.015

KobayashiT,WalshMC,ChoiY.TheroleofTRAF6 in signal transduction and the immune response. Microbes and Infection 2004; 6:1333-1338. https://doi.org/10.1016/j.micinf.2004.09.001

Lan JF, Zhou J, Zhang XW, Wang ZH, Zhao XF, Ren Q, Wang JX. Characterization of an immune deficiency homolog (IMD) in shrimp (Fenneropenaeus chinensis) and crayfish (Procambarus clarkii). Dev Comp Immunol 2013; 41:608-617. https://doi.org/10.1016/j.dci.2013.07.004

Lee SY, Söderhäll K. Early events in crustacean innate immunity. Fish Shellfish Immunol 2002; 12:421-437. https://doi.org/10.1006/fsim.2002.0420

Liu Y, Song L, Sun Y, Liu T, Hou F, Liu X. Comparison of immune response in Pacific white shrimp, Litopenaeus vannamei, after knock down of Toll and IMD gene in vivo. Dev Comp Immunol 2016; 60:41-52. https://doi.org/10.1016/j.dci.2016.02.004

RayAJ,LotzJM. Shrimp(Litopenaeusvannamei) production and stable isotope dynamics in clearwater recirculating aquaculture systems versus biofloc systems. Aquac Res 2017; 48:43904398. https://doi.org/10.1111/are.13262

Rubio-Castro A, Luna-González A, ÁlvarezRuiz P, Escamilla-Montes R, Fierro-Coronado JA, López-León P, Flores-Miranda MDC, DiartePlata G. Survival and immune-related gene expression in Litopenaeus vannamei co-infected with WSSV and Vibrio parahaemolyticus. Aquaculture 2016; 464:692-698. https://doi. org/10.1016/j.aquaculture.2016.08.024

Schveitzer R., Zanetti Leite TS, Orteney 
NE, Temistocles Menezes F, Dias Medeiros I. Format and mode of artificial substrate fixation affect the performance of Litopenaeus vannamei in high-density rearing systems. Aquac Res 2018; 49:1357-1362. https://doi.org/10.1111/are.13561

Söderhäll K, Cerenius L. Crustacean immunity. Ann Rev Fish Dis 1992; 2:3-23. https://doi.org/10.1016/0959-8030(92)90053-Z

Strickland JDH, Parsons TH. A Practical Handbook of Seawater Analysis. Fish Research Board of Canada Bulletin, Ottawa, Canada; 1972.

Wang PH, Gu ZH, Huang XD, Liu BD, Deng XX, Ai HS, Wang J, Yin ZX, Weng $\mathrm{SP}, \mathrm{Yu} X Q$, He JG. An immune deficiency homolog from the white shrimp, Litopenaeus vannamei, activates antimicrobial peptide genes. Mol Immunol 2009; 46:1897-1904. https://doi.org/10.1016/j.molimm.2009.01.005
Wang PH, Wan DH, Gu ZH, Deng XX, Weng $\mathrm{SP}$, Yu XQ, He JG. Litopenaeus vannamei tumor necrosis factor receptor-associated factor 6 (TRAF6) responds to Vibrio alginolyticus and white spot syndrome virus (WSSV) infection and activates antimicrobial peptide genes. Dev Comp Immunol 2011; 35:105-114. https://doi.org/10.1016/j.dci.2010.08.013

Wang XW, Wang JX. Pattern recognition receptors acting in innate immune system of shrimp against pathogen infections. Fish Shellfish Immunol 2013; 34:981-989. https://doi.org/10.1016/j.fsi.2012.08.008

$\mathrm{Xu}$ WJ, Pan LQ. Enhancement of immune response and antioxidant status of Litopenaeus vannamei juvenile in biofloc-based culture tanks manipulating high $\mathrm{C} / \mathrm{N}$ ratio of feed input. Aquaculture 2013; 412-413:117-124. https:// doi.org/10.1016/j.aquaculture.2013.07.017

Zhang M, Mab J, Lei K, Xu X. Molecular cloning and characterization of a class II ADP ribosylation factor from the shrimp Marsupenaeus japonicus. Fish Shellfish Immunol 2010; 28:128-133. https://doi.org/10.1016/j.fsi.2009.10.008 